\title{
Larval and early juvenile development of Lithodes santolla (Molina, 1782) (Decapoda: Anomura: Lithodidae) reared at different temperatures in the laboratory
}

\author{
Klaus Anger ${ }^{\mathrm{a}, *}$, Gustavo A. Lovrich ${ }^{\mathrm{b}}$, \\ Sven Thatje ${ }^{\mathrm{c}}$, Javier A. Calcagno ${ }^{\mathrm{d}}$ \\ a Biologische Anstalt Helgoland, Stiftung Alfred-Wegener-Institut für Polar-und Meeresforschung, \\ 27498 Helgoland, Germany \\ ${ }^{\mathrm{b}}$ Centro Austral de Investigaciones Cientificas (CADIC), 9410 Ushuaia, Argentina \\ ${ }^{c}$ Alfred-Wegener-Institut für Polar-und Meeresforschung, 27568 Bremerhaven, Germany \\ ${ }^{\mathrm{d}}$ Facultad de Ciencias Exactas y Naturales, Universidad de Buenos Aires, Argentina
}

Received 25 November 2003; accepted 15 January 2004

\begin{abstract}
The southern king crab, Lithodes santolla Molina, is distributed in cold-temperate and subantarctic waters ranging from the southeastern Pacific island of Chiloé (Chile) and the deep Atlantic waters off Uruguay, south to the Beagle Channel (Tierra del Fuego, Argentina/Chile). Recent investigations have shown that its complete larval development from hatching to metamorphosis, comprising three zoeal stages and a megalopa, is fully lecithotrophic, i.e. independent of food. In the present study, larvae were individually reared in the laboratory at seven constant temperatures ranging from 1 to $18{ }^{\circ} \mathrm{C}$, and rates of survival and development through successive larval and early juvenile stages were monitored throughout a period of 1 year. The highest temperature $\left(18{ }^{\circ} \mathrm{C}\right)$ caused complete mortality within 1 week; only a single individual moulted under this condition, 2 days after hatching, to the second zoeal stage, while all other larvae died later in the zoea I stage. At the coldest condition $\left(1{ }^{\circ} \mathrm{C}\right), 71 \%$ of the larvae reached the zoea III stage, but none of these moulted successfully to a megalopa. A temperature of $3{ }^{\circ} \mathrm{C}$ allowed for some survival to the megalopa stage (17-33\% in larvae obtained from two different females), but only a single individual passed successfully, 129 days after hatching, through metamorphosis to the first juvenile crab instar. At all other experimental conditions $\left(6,9,12\right.$ and $\left.15{ }^{\circ} \mathrm{C}\right)$, survival through metamorphosis varied among temperatures and two hatches from $29 \%$ to $90 \%$ without showing a
\end{abstract}

* Corresponding author. Tel.: +49-4725-819348.

E-mail address: kanger@awi-bremerhaven.de (K. Anger). 
consistent trend. The time of nonfeeding development from hatching to metamorphosis lasted, on average, from 19 days at $15{ }^{\circ} \mathrm{C}$ to 65 days at $6{ }^{\circ} \mathrm{C}$. The relationship between the time of development through individual larval or juvenile stages $(D)$ and temperature $(T)$ was described as a power function $\left(D=a T^{b}\right.$, or $\left.\log [D]=\log [a] b \log [T]\right)$. The same model was also used to describe the temperature dependence of cumulative periods of development from hatching to later larval or juvenile stages. One year after hatching, the 7 th $\left(6{ }^{\circ} \mathrm{C}\right)$ to 9 th $\left(15^{\circ} \mathrm{C}\right) \mathrm{crab}$ instar was reached. Under natural temperature conditions in the region of origin of our material (Beagle Channel, Argentina), $L$. santolla should reach metamorphosis in October-December, i.e. ca. 2 months after hatching (taking place in winter and early spring). Within 1 year from hatching, the crabs should grow approximately to juvenile instars VII-VIII. Our results indicate that the early life-history stages of L. santolla tolerate moderate cold stress as well as planktonic food-limitation in winter, implying that this species is well adapted to subantarctic environments with low temperatures and a short seasonal plankton production.

(C) 2004 Elsevier B.V. All rights reserved.

Keywords: Lithodidae; Larval development; Temperature; Reproductive strategies

\section{Introduction}

While the diversity of decapod crustaceans, in general, tends to decline in coldtemperate and subpolar waters as compared to warm-temperate and tropical regions, the number of lithodid crab species remains stable or increases with increasing latitude (e.g. Arntz et al., 1994, 1997; Klages et al., 1995; Gorny, 1999; Zaklan, 2002). Recent experimental studies suggested that this deviating distributional pattern of the Lithodidae among the reptant decapods is due to special adaptations of their early life-history stages to conditions of cold and food-limitation in high latitudes, namely tolerance of low temperatures and lecithotrophic (i.e. food-independent) larval development (Anger et al., 2003; Calcagno et al., 2003, 2004; Kattner et al., 2003; Lovrich et al., 2003; Thatje et al., 2003).

Since lithodids have generally a large body size and a high market value as "king crabs" or "stone crabs", several species are commercially fished, representing economically valuable fishery resources in subpolar regions (Dawson, 1989; Lovrich, 1997; Sundet and Hjelset, 2002). The southern king crab, Lithodes santolla Molina, is one of those species, although its commercially exploited populations have dramatically declined in recent years, due to heavy overfishing in preceding times (Lovrich and Vinuesa, 1999). L. santolla is distributed in a large area along the southeastern Pacific and southwestern Atlantic coasts, stretching from the subantarctic waters of the Beagle Channel (Tierra del Fuego, southernmost parts of Argentina and Chile; $55^{\circ} \mathrm{S}$ ) to the cold-temperate region around the island of Chiloé (southern-central Chile; $42^{\circ} \mathrm{S}$; see Retamal, 1981; Boschi et al., 1992; Gorny, 1999) and the deeper parts (ca. $700 \mathrm{~m}$ depth) of the continental slope off Uruguay (Vinuesa, 1991). Its larval development comprises three zoeal stages and a megalopa which were morphologically described by Campodonico (1971) and McLaughlin et al. (2001). Recent biochemical and elemental analyses of fed and unfed larvae showed that all four larval stages are completely nonfeeding, which was interpreted as an adaptation to early development under conditions of low water temperature and low or 
short planktonic productivity during the austral winter (Calcagno et al., 2003, 2004; Kattner et al., 2003; Lovrich et al., 2003).

In the present study, we reared larval and early juvenile southern king crabs at various constant temperatures in the laboratory (1) to identify the tolerated or preferred thermal range for successful postembryonic development and growth, and (2) to quantify the effect of variation in temperature on the rate of moulting and development through the early lifehistory stages.

\section{Materials and methods}

The capture, maintenance, and transport of $L$. santolla as well as the rearing of their larvae were described in detail by Lovrich et al. (2003). Briefly, ovigerous females were collected in April 2001 in the Beagle Channel (Tierra del Fuego, southern Argentina; 54 ${ }^{\circ} 53.8^{\prime} \mathrm{S}$, $68^{\circ} 17.0^{\prime} \mathrm{W}$ ) using commercial fishing boats (Lovrich, 1997), subsequently kept in submerged cages in the Beagle Channel, and eventually transported with the German research icebreaker "Polarstern" to the marine biological laboratory Helgoland, Germany (Biologische Anstalt Helgoland, BAH). Subsequently, the crabs were maintained in flowthrough seawater aquaria at constant $6{ }^{\circ} \mathrm{C}$, ca. 32\%o salinity, and a 12:12-h light/dark cycle.

Freshly hatched larvae were collected in filters receiving the overflow from the aquaria. Since most larvae hatched at night, sampling was done every morning. Filters were cleaned every evening to ensure that larval age did not vary more than by $12 \mathrm{~h}$. Actively swimming larvae obtained from one female (A) were randomly selected and subsequently reared in individual $100-\mathrm{ml}$ bowls kept under the same conditions of salinity and light. As rearing temperatures, we tested $1,3,6,9,12,15$, and $18{ }^{\circ} \mathrm{C}$. Since L. santolla releases only low numbers of larvae per night (normally $<100$, see Thatje et al., 2003), we were forced to start "parallel" experiments (i.e. testing different rearing temperatures with larvae originating from the same female) using sibling larvae that hatched on different days. An additional (less complete) series of experiments was conducted with larvae from a second female (hatch B; testing only $3,6,9$, and $12{ }^{\circ} \mathrm{C}$ ). The initial number of larvae per treatment and hatch was $n=48$.

The larvae were reared without addition of food, since previous experiments (McLaughlin et al., 2001; Lovrich et al., 2003; Kattner et al., 2003; Calcagno et al., 2004) had shown that all larval stages of $L$. santolla are nonfeeding. From the day of metamorphosis, juvenile crabs were fed with Artemia nauplii (Argent Chemical Laboratories, USA). At $9-15^{\circ} \mathrm{C}$, the culture water (in juveniles also food) was changed every other day, at lower temperatures every third day, at $18^{\circ} \mathrm{C}$ daily. In all treatments, the larvae or juveniles were checked daily for moults or mortality. Due to technical problems, the moult from the zoea II-III stage was not recorded in larvae from hatch B reared at 3 and $12{ }^{\circ} \mathrm{C}$, so that no data of development duration through these two individual stages were obtained in these exceptional cases (Table 2). Upon reaching the benthic megalopa, a piece of nylon mesh was placed in each bowl as an artificial substrate, which facilitated the settlement and metamorphosis of the megalopa.

The rearing experiments with hatch A were continued throughout one year, from August 2001 to August 2002, while the additional experiments with hatch B were 
terminated earlier (at 6 and $9{ }^{\circ} \mathrm{C}$ as soon as the crab stage II was reached; at $12{ }^{\circ} \mathrm{C}$ in the crab IV). Due to an accident, the experiment with hatch A larvae reared at $12{ }^{\circ} \mathrm{C}$ was prematurely terminated during the crab III instar, so that no data for later juvenile instars in this treatment were obtained.

Our statistical analyses followed Sokal and Rohlf (1995). One-way ANOVA followed by comparisons between pairs of means was used for comparing survival and time of development at each larval stage. The durations of individual (larval or juvenile) stages as well as cumulative periods of development (e.g. from hatching to metamorphosis) were described as power functions of temperature (i.e., as linear regressions after logtransformation of both variables). Arithmetic mean values obtained from different females rather than individual data were used as replicate values in regression analyses. Slope parameters of the linearized regressions were compared with a test for heterogeneity of slopes using the $F$ statistics. Where average values with error estimates are given in the text or in figures and tables, these represent arithmetic mean values \pm one standard deviation (S.D.).

\section{Results}

\subsection{Rates of survival}

The rate of survival through successive larval and juvenile stages varied greatly among the various temperature conditions and the two hatches obtained from different females (Table 1). In the temperature range for which sufficient comparative data are available for both hatches $\left(6-12{ }^{\circ} \mathrm{C}\right)$, larvae from hatch $\mathrm{B}$ showed generally a higher cumulative rate of survival to metamorphosis and through the first juvenile crab instar than those obtained from hatch A. Zoeal survival at $3{ }^{\circ} \mathrm{C}$, however, was higher in larvae from hatch A (Table 1).

When larval survival rates are compared in the full range of experimental temperatures, we see clearly that the extreme conditions of 1 and $18{ }^{\circ} \mathrm{C}$ exerted thermal stress not allowing for successful development through metamorphosis. While most larvae $(71 \%)$ survived at $1{ }^{\circ} \mathrm{C}$ through two zoeal moults to the zoea III stage, none of these was able to moult to the megalopa. At the second coldest condition, $3{ }^{\circ} \mathrm{C}, 17-33 \%$ of the larvae originating from hatches $\mathrm{B}$ and $\mathrm{A}$, respectively, developed successfully to the megalopa stage. A single individual (from hatch A) survived in this treatment through metamorphosis to the first juvenile crab instar. It died two months later without moulting again. At the highest temperature tested $\left(18{ }^{\circ} \mathrm{C}\right)$, most larvae $(98 \%)$ remained alive for up to one week but all of these died eventually without moulting. A single individual reached 2 days after hatching the second zoeal stage, but it also died the next day. The intermediate temperature conditions $\left(6-15^{\circ} \mathrm{C}\right)$ allowed for substantial $(35-90 \%)$ survival through complete larval development to metamorphosis.

When the experiments were terminated, 1 year after hatching, the survivors had maximally reached juvenile instar VI $\left(6{ }^{\circ} \mathrm{C}\right)$, VII $\left(9{ }^{\circ} \mathrm{C}\right)$, and IX $\left(15^{\circ} \mathrm{C}\right)$, respectively, with cumulative survival rates ranging from $8 \%$ to $17 \%$ (Table 1 ); the $12{ }^{\circ} \mathrm{C}$ treatment was accidentally lost during the crab III stage so that it cannot be included in this comparison. 
Table 1

L. santolla. Rates of survival in individual developmental stages (in \% of survivors to a given stage) in larvae obtained from two different females (A, B); cumulative survival (from hatching through a given stage, cum. $\%$; in $\%$ of initial number at hatching, $n=48$, highlighted in italics)

\begin{tabular}{|c|c|c|c|c|c|c|c|c|c|c|c|c|c|c|c|c|c|c|c|c|c|c|}
\hline \multirow{3}{*}{$\begin{array}{l}T \\
\left({ }^{\circ} \mathrm{C}\right)\end{array}$} & \multirow[t]{3}{*}{ Female } & \multicolumn{21}{|l|}{ Stage } \\
\hline & & \multirow{2}{*}{$\frac{\text { Zoea I }}{\%}$} & \multicolumn{2}{|c|}{ Zoea II } & \multicolumn{2}{|c|}{ Zoea III } & \multicolumn{2}{|c|}{ Megalopa } & \multicolumn{2}{|c|}{$\underline{\text { Crab I }}$} & \multicolumn{2}{|c|}{ Crab II } & \multicolumn{2}{|c|}{ Crab III } & \multicolumn{2}{|c|}{ Crab IV } & \multicolumn{2}{|c|}{$\underline{\text { Crab V }}$} & \multicolumn{2}{|c|}{$\underline{\text { Crab VI }}$} & Crab VII & Crab VIII \\
\hline & & & $\%$ & $\overline{\text { cum. } \%}$ & $\%$ & $\overline{\text { cum. } \%}$ & $\%$ & $\overline{\text { cum. } \%}$ & $\%$ & $\overline{\operatorname{cum} . \%}$ & $\%$ & $\overline{\operatorname{cum} . \%}$ & $\%$ & $\overline{\text { cum. } \%}$ & $\%$ & $\overline{\operatorname{cum} . \%}$ & $\%$ & $\overline{\text { cum. } \%}$ & $\%$ & $\overline{\text { cum. } \%}$ & $\overline{\%} \quad$ cum. $\%$ & $\overline{\% \quad \text { cum. } \%}$ \\
\hline 1 & A & 75 & 89 & 71 & 0 & 0 & & & & & & & & & & & & & & & & \\
\hline \multirow[t]{2}{*}{3} & A & 98 & 62 & 63 & 55 & 33 & 13 & 2 & & & & & & & & & & & & & & \\
\hline & B & 77 & 51 & 46 & 42 & 17 & 0 & 0 & & & & & & & & & & & & & & \\
\hline \multirow[t]{2}{*}{6} & A & 94 & 89 & 83 & 93 & 77 & 95 & 73 & 94 & 69 & 85 & 58 & 61 & 33 & 47 & 17 & 100 & 17 & & & & \\
\hline & B & 96 & 85 & 81 & 97 & 79 & 90 & 71 & 100 & 71 & & & & & & & & & & & & \\
\hline \multirow[t]{2}{*}{9} & A & 90 & 67 & 60 & 62 & 38 & 78 & 29 & 93 & 27 & 100 & 27 & 92 & 25 & 50 & 13 & 83 & 10 & 80 & 8 & & \\
\hline & B & 94 & 100 & 94 & 98 & 90 & 98 & 90 & 88 & 79 & & & & & & & & & & & & \\
\hline \multirow[t]{2}{*}{12} & A & 90 & 67 & 60 & 79 & 48 & 74 & 35 & 47 & 17 & 50 & 8 & & & & & & & & & & \\
\hline & B & 90 & 79 & 81 & 85 & 69 & 93 & 56 & 85 & 48 & 78 & 38 & 17 & 8 & & & & & & & & \\
\hline 15 & $\mathrm{~A}$ & 94 & 91 & 85 & 90 & 77 & 84 & 65 & 94 & 60 & 72 & 44 & 86 & 38 & 83 & 31 & 93 & 29 & 57 & 17 & $88 \quad 15$ & $71 \quad 10$ \\
\hline 18 & A & 2 & 0 & 0 & & & & & & & & & & & & & & & & & & \\
\hline
\end{tabular}


Table 2

L. santolla. Time of development through successive larval and early juvenile stages (days, mean \pm 1 standard deviation) in larvae obtained from two different females (A, B) and reared at different temperatures $\left(T,{ }^{\circ} \mathrm{C}\right)$; nd $=$ not determined; $*=$ no S.D. available $(n=1)$

\begin{tabular}{|c|c|c|c|c|c|c|c|c|c|c|c|c|c|c|c|c|c|c|c|c|c|c|c|c|c|}
\hline \multirow{3}{*}{$\begin{array}{l}T \\
\left({ }^{\circ} \mathrm{C}\right)\end{array}$} & \multirow[t]{3}{*}{ Female } & \multicolumn{24}{|c|}{ Stage } \\
\hline & & \multicolumn{2}{|c|}{ Zoea I } & \multicolumn{2}{|c|}{ Zoea II } & \multicolumn{2}{|c|}{ Zoea III } & \multicolumn{2}{|c|}{ Megalopa } & \multicolumn{2}{|c|}{ Crab I } & \multicolumn{2}{|c|}{ Crab II } & \multicolumn{2}{|c|}{ Crab III } & \multicolumn{2}{|c|}{ Crab IV } & \multicolumn{2}{|c|}{ Crab V } & \multicolumn{2}{|c|}{ Crab VI } & \multicolumn{2}{|c|}{ Crab VII } & \multicolumn{2}{|c|}{ Crab VIII } \\
\hline & & $x$ & \pm S.D. & $x$ & \pm S.D. & $x$ & \pm S.D. & $x$ & \pm S.D. & $x$ & \pm S.D. & $x$ & \pm S.D. & $x$ & \pm S.D. & $x$ & \pm S.D. & $x$ & \pm S.D. & $x$ & \pm S.D. & $x$ & \pm S.D. & $x$ & \pm S.D. \\
\hline 1 & A & 17.5 & 3.0 & 22.6 & 3.1 & & & & & & & & & & & & & & & & & & & & \\
\hline \multirow[t]{2}{*}{3} & A & 10.1 & 2.6 & 24.1 & 4.7 & 24.3 & 6.9 & 80.0 & $*$ & & & & & & & & & & & & & & & & \\
\hline & B & 13.6 & 3.1 & nd & nd & nd & nd & & & & & & & & & & & & & & & & & & \\
\hline \multirow[t]{2}{*}{6} & A & 5.6 & 1.9 & 7.8 & 0.5 & 11.0 & 0.6 & 36.1 & 1.8 & 42.8 & 2.9 & 56 & 9 & 64 & 10 & 67 & 6 & 68 & 10 & & & & & & \\
\hline & B & 5.5 & 0.8 & 8.6 & 1.2 & 10.6 & 0.8 & 38.7 & 2.4 & 46.1 & 4.2 & & & & & & & & & & & & & & \\
\hline \multirow[t]{2}{*}{9} & A & 3.2 & 0.4 & 4.4 & 0.6 & 6.9 & 0.5 & 29.1 & 1.4 & 30.0 & 1.8 & 38 & 6 & 39 & 7 & 48 & 13 & 56 & 7 & 62 & 17 & & & & \\
\hline & $\mathrm{B}$ & 3.8 & 0.5 & 4.4 & 0.5 & 7.5 & 0.7 & 30.1 & 3.2 & 31.9 & 4.2 & & & & & & & & & & & & & & \\
\hline \multirow[t]{2}{*}{12} & A & 2.4 & 0.5 & 4.2 & 0.7 & 4.9 & 0.4 & 21.6 & 2.6 & 22.8 & 1.7 & 32 & 5 & & & & & & & & & & & & \\
\hline & B & 3.1 & 0.4 & nd & nd & nd & nd & 22.2 & 2.8 & 26.4 & 3.1 & 34 & 9 & & & & & & & & & & & & \\
\hline 15 & A & 3.0 & 0.4 & 2.6 & 0.6 & 4.2 & 0.5 & 15.1 & 1.0 & 20.5 & 3.3 & 23 & 5 & 28 & 9 & 25 & 9 & 30 & 9 & 32 & 7 & 36 & 7 & 54 & 14 \\
\hline 18 & A & 2.0 & $*$ & & & & & & & & & & & & & & & & & & & & & & \\
\hline
\end{tabular}


Table 3

L. santolla. Cumulative time of development from hatching to successive stages (days, mean \pm 1 standard deviation) in larvae obtained from two different females (A, B) and reared at different temperatures $\left(T,{ }^{\circ} \mathrm{C}\right) ;{ }^{*}=$ no S.D. available $(n=1)$

\begin{tabular}{|c|c|c|c|c|c|c|c|c|c|c|c|c|c|c|c|c|c|c|c|c|c|}
\hline \multirow{3}{*}{$\begin{array}{l}\text { T } \\
\left({ }^{\circ} \mathrm{C}\right)\end{array}$} & \multirow[t]{3}{*}{ Female } & \multicolumn{20}{|c|}{ Stage } \\
\hline & & \multicolumn{2}{|c|}{ Megalopa } & \multicolumn{2}{|c|}{ Crab I } & \multicolumn{2}{|c|}{ Crab II } & \multicolumn{2}{|c|}{ Crab III } & \multicolumn{2}{|c|}{ Crab IV } & \multicolumn{2}{|c|}{ Crab V } & \multicolumn{2}{|c|}{ Crab VI } & \multicolumn{2}{|c|}{ Crab VII } & \multicolumn{2}{|c|}{ Crab VIII } & \multicolumn{2}{|c|}{ Crab IX } \\
\hline & & $x$ & \pm S.D. & $x$ & \pm S.D. & $x$ & \pm S.D. & $x$ & \pm S.D. & $x$ & \pm S.D. & $x$ & \pm S.D. & $x$ & \pm S.D. & $x$ & \pm S.D. & $x$ & \pm S.D. & $x$ & \pm S.D. \\
\hline \multirow[t]{2}{*}{3} & A & 56.9 & 4.4 & 129 & $*$ & & & & & & & & & & & & & & & & \\
\hline & B & 51.3 & 5.3 & & & & & & & & & & & & & & & & & & \\
\hline \multirow[t]{2}{*}{6} & A & 24.0 & 0.9 & 60.1 & 2.1 & 103 & 4.0 & 161 & 15 & 221 & 15 & 289 & 16 & 356 & 11 & & & & & & \\
\hline & B & 24.6 & 0.8 & 64.9 & 10 & 110 & 5.2 & & & & & & & & & & & & & & \\
\hline \multirow[t]{2}{*}{9} & A & 14.2 & 0.4 & 43.4 & 1.3 & 73.4 & 2.0 & 111 & 6 & 150 & 11 & 203 & 20 & 263 & 24 & 330 & 33 & & & & \\
\hline & $\mathrm{B}$ & 15.7 & 0.6 & 45.8 & 3.1 & 77.3 & 5.8 & & & & & & & & & & & & & & \\
\hline \multirow[t]{2}{*}{12} & A & 11.4 & 0.6 & 32.9 & 2.4 & 56.1 & 4.2 & 90 & 6 & & & & & & & & & & & & \\
\hline & B & 12.6 & 0.5 & 34.7 & 2.8 & 60.9 & 4.6 & 95 & 10 & & & & & & & & & & & & \\
\hline 15 & A & 9.7 & 0.5 & 19.3 & 1.0 & 45.3 & 3.9 & 68 & 6 & 97 & 12 & 121 & 13 & 150 & 19 & 187 & 22 & 226 & 26 & 278 & 20 \\
\hline
\end{tabular}




\subsection{Rates of development}

Development durations of individual larval and juvenile stages are given in Table 2; cumulative development times (from hatching) are shown in Table 3. No statistically significant differences in individual stage durations were observed between larvae originating from two different females (Table 2). As a consequence, also the cumulative durations to successive stages at identical temperatures were generally similar and differences were statistically insignificant (Table 3).

Increasing temperature had in general a significant accelerating effect on development, especially in the lower temperature range. As a single exception, there was no significant difference between zoea II durations recorded in hatch $\mathrm{A}$ at 1 and $3{ }^{\circ} \mathrm{C}$ (Table 2). While an increase from 3 to 6 or from 6 to $9{ }^{\circ} \mathrm{C}$ caused in all three zoeal stages a substantial (and statistically highly significant; all $P<0.0001$ ) decrease in moult-cycle durations, the stage durations measured at 9 and $12{ }^{\circ} \mathrm{C}$ were much more similar to each other. With the exception of the zoea II stage (hatch A) and crab I (hatch B), however, all differences between these two temperatures were statistically significant. The differences observed between 12 and $15{ }^{\circ} \mathrm{C}$ were still smaller; in the zoea I and crab I stages they were statistically insignificant $(P>0.05)$.

Within the entire temperature range tested in this study $\left(1-18{ }^{\circ} \mathrm{C}\right)$, the zoea I lasted on average $2-18$ days. The zoea II took 3-23 days (data available only for the range from 1 to $15^{\circ} \mathrm{C}$ ), and the zoea III stage lasted $4-24$ days (at $3-15^{\circ} \mathrm{C}$ ). The mean duration of the megalopa varied in the same temperature range from 15 to 80 days (Table 2).

Complete zoeal development from hatching to the moult of the zoea III to the megalopa stage varied, at temperatures of $3-15{ }^{\circ} \mathrm{C}$, from about $10-57$ days, while the complete nonfeeding larval development from hatching to metamorphosis took from 19 days (at 15 ${ }^{\circ} \mathrm{C}$ ) to 129 days (at $3{ }^{\circ} \mathrm{C}$ ), i.e. from less than 3 weeks to more than 4 months (Table 3 ).

The moult-cycle durations of successive juvenile instars also showed consistently a decrease with increasing temperature. The duration of the crab I stage, for instance, varied from 20 days (at $\left.15^{\circ} \mathrm{C}\right)$ to 46 days $\left(6^{\circ} \mathrm{C}\right)$. As another consistent trend, the young crab

Table 4

L. santolla. Fitted parameters $(a, b)$ and coefficients of determination $\left(r^{2}\right)$ of nonlinear regression equations (power functions, $\left.y=a T^{b}\right)$ describing development time ( $y$, days) as a function of temperature $\left(T,{ }^{\circ} \mathrm{C}\right)$; (i) time of development in individual stages (dev./stage); (ii) cumulative time of development from hatching to later stages (cum.dev.)

\begin{tabular}{|c|c|c|c|c|c|c|c|}
\hline \multirow[t]{2}{*}{ Parameter } & \multicolumn{7}{|l|}{ Stage } \\
\hline & Zoea I & Zoea II & Zoea III & Megalopa & Crab I & Crab II & Crab III \\
\hline \multicolumn{8}{|c|}{ (i) Dev./stage } \\
\hline$a$ & 22.7 & 33.7 & 79.6 & 200.1 & 201.5 & 273.2 & \\
\hline$b$ & -0.812 & -0.860 & -1.102 & -0.906 & -0.848 & -0.879 & \\
\hline$r^{2}$ & 0.934 & 0.855 & 0.995 & 0.936 & 0.971 & 0.945 & \\
\hline \multicolumn{8}{|c|}{ (ii) Cum.dev. } \\
\hline$a$ & & & 52.8 & 173.3 & 430.6 & 537.8 & 788.5 \\
\hline$b$ & & & -0.814 & -1.086 & -1.061 & -0.900 & -0.881 \\
\hline$r^{2}$ & & & 0.916 & 0.990 & 0.960 & 0.985 & 0.974 \\
\hline
\end{tabular}


stages showed at each temperature increasing moult-cycle durations and an increasing variability in successively later instars (Table 2). At $15{ }^{\circ} \mathrm{C}$, for example, the crab I instar lasted, on average, 20.5 \pm 3.3 days, while the time in the crab VIII stage was more than twice as long $\left(54 \pm 14\right.$ days). At $9{ }^{\circ} \mathrm{C}$, the moult-cycle duration doubled from the crab I to the crab VI ( $30 \pm 1.8$ vs. $62 \pm 17$ days).
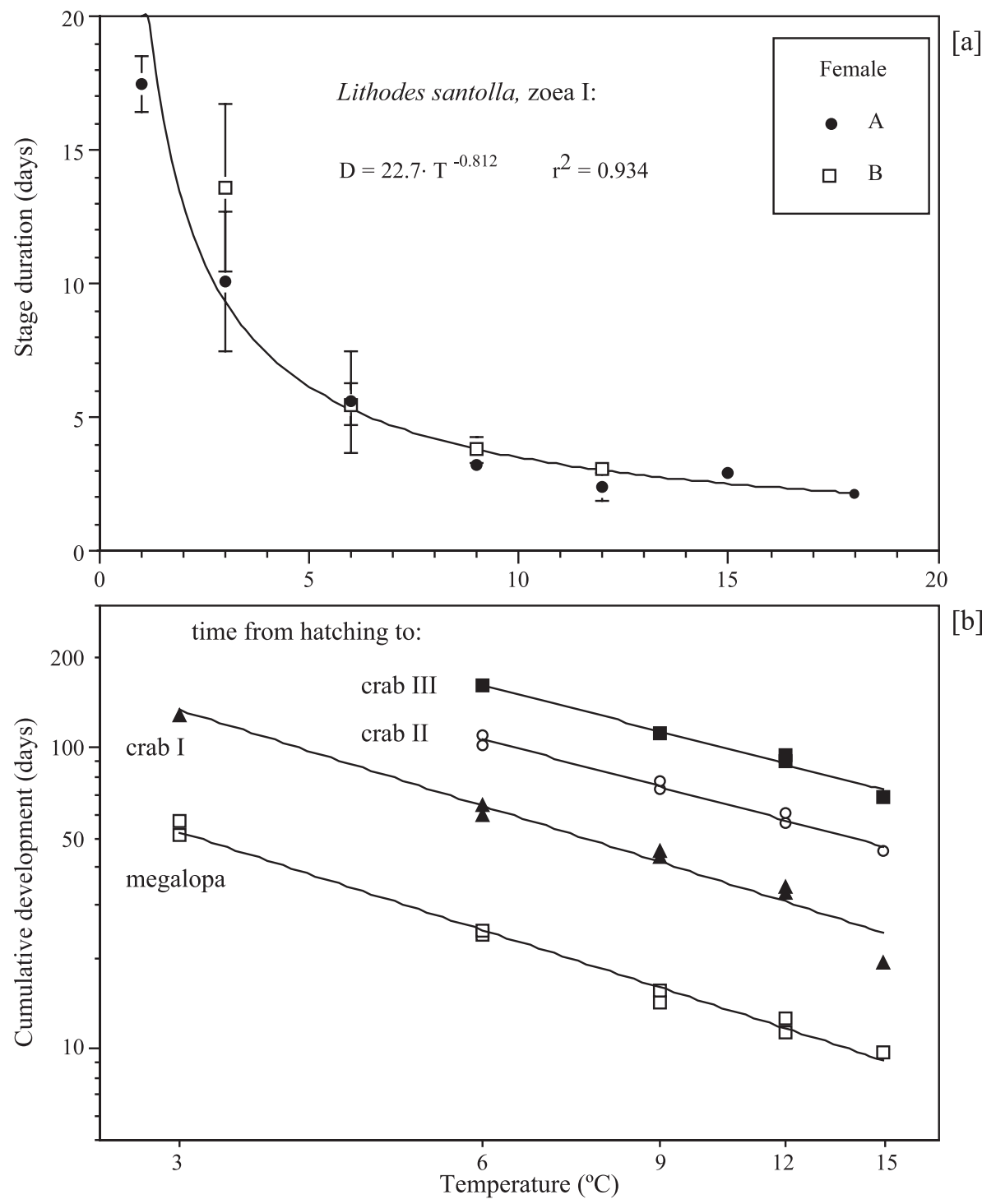

Fig. 1. L. santolla. Duration of larval and early juvenile development in relation to temperature. (a) Illustration of the nonlinear relationship (power function, see text): zoea I stage duration at $1-18{ }^{\circ} \mathrm{C}$; (b) cumulative time of development from hatching to later stages (megalopa-crab III, at $3-15^{\circ} \mathrm{C}$ ). 
The patterns of development duration ( $D$, in days) in relation to temperature $\left(T\right.$, in $\left.{ }^{\circ} \mathrm{C}\right)$ could be described as a power function, $D=a T^{b}$, where $a$ and $b$ are fitted parameters (Table 4). Almost all coefficients of determination $\left(r^{2}\right)$ were $>0.9$ (only exception: duration of the zoea II, with $\left.r^{2}=0.855\right)$. The best fit between observed and predicted data $\left(r^{2} \geq 0.99\right)$ was found in the duration of the zoea III stage and in the cumulative time of development from hatching to metamorphosis.

These nonlinear patterns are illustrated in Fig. 1a using the untransformed zoea I data as an example. Linearized regressions (after log-log transformation) of cumulative development times in relation to temperature are shown in Fig. $1 \mathrm{~b}$ for all individual stages where complete data sets for a minimum of four different temperatures were available (i.e., up to the crab III stage, cf. Table 3). The slopes of these regression lines were not significantly different from each other (ANCOVA, $P>0.05$ ), indicating a similar degree of temperature dependence in successive developmental stages.

\section{Discussion}

The early life history of the southern king crab, L. santolla, has until recently very little been known, although this species used to have, and potentially still has, a high economic value as a fishery resource in southern Argentina and Chile. Moreover, there is considerable interest in the commercial aquaculture and stock enhancement of king crabs in general (for discussion and references, see, e.g. Konishi, 1998; Konishi and Shikatani, 1999; Stevens, 2003). Thus, an improved knowledge of the early development and growth of king crabs should be crucial not only for resource management and the implementation of fishery regulations (Lovrich, 1997; Lovrich and Vinuesa, 1999), but it also is a major prerequisite for the development of technically and commercially feasible artificial cultivation techniques.

Recent studies on the same species (Kattner et al., 2003; Lovrich et al., 2003) showed that the entire larval development from hatching to metamorphosis is in L. santolla fully independent of food. This trait should greatly facilitate the otherwise much more complicated, labour-intensive, and expensive rearing from the egg to the first juvenile stage. The present study now provides an indication of the optimal temperature range for larviculture: it should be most successful between ca. 6 and $15^{\circ} \mathrm{C}$; the initial rearing, at least through the zoeal stages, should also be possible at lower temperatures down to about $3{ }^{\circ} \mathrm{C}$. For rearing facilities located in the Magellan region, where average sea surface temperatures vary seasonally between about 5 and $10{ }^{\circ} \mathrm{C}$ (Fig. 2), our results indicate that the larvae of this king crab species can simply be reared under ambient-temperature flowthrough conditions.

The same holds true for rearing sites at the northern distributional limit of this species in the Pacific, although the average water temperatures in this region are about $4-9{ }^{\circ} \mathrm{C}$ higher than in the Beagle Channel (Fig. 2). Since the larvae of this species hatch during the austral winter and spring, i.e. from early August to October (present observations; cf. Lovrich and Vinuesa, 1999; Thatje et al., 2003), ambient water temperatures of about 10 $12{ }^{\circ} \mathrm{C}$ in southern-central Chile (see Fig. 2) would still be within the optimal range for larval rearing. Later juvenile stages, however, might have problems at summer temper- 


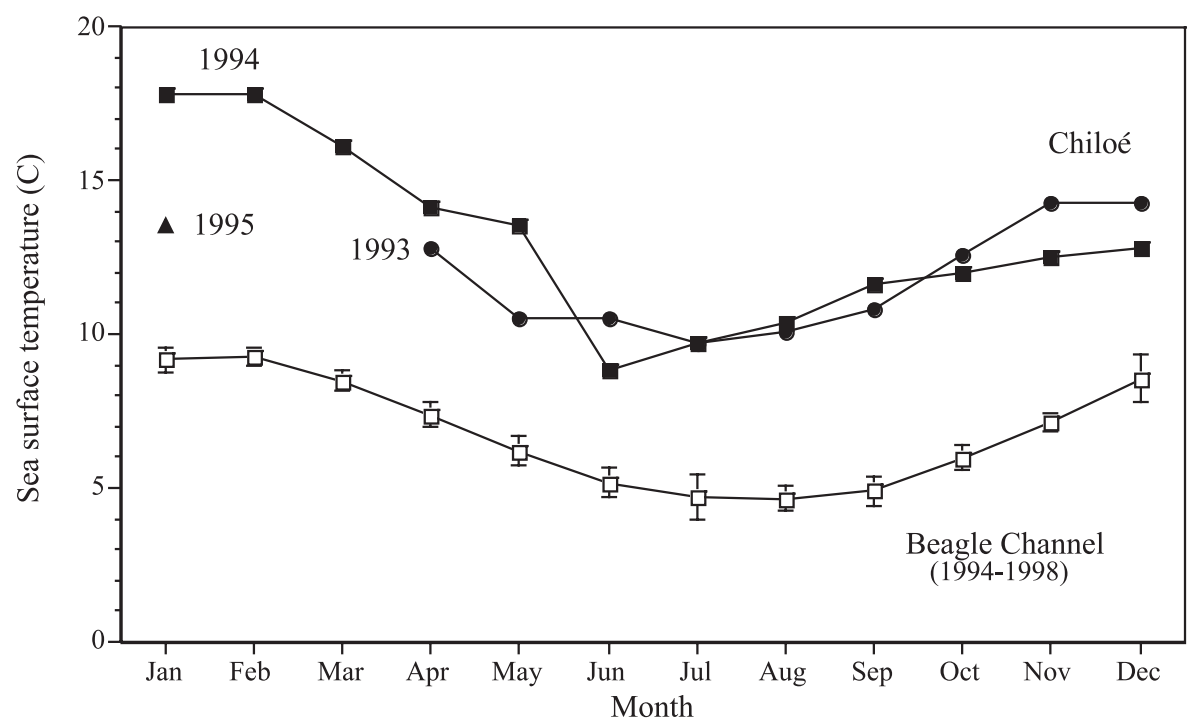

Fig. 2. Thermal climate near the southern and northern limits of geographic distribution of L. santolla: seasonal variation of average sea surface temperatures in the Beagle Channel $\left(55^{\circ} \mathrm{S}\right.$; monthly mean values $\pm \mathrm{S} . \mathrm{D}$. for the period 1994-1998; Servicio Centralizado de Documentación, CADIC, unpublished data; open squares) and off the Pacific Island of Chiloé $\left(42^{\circ} \mathrm{S}\right.$; monthly mean values; data from Lardies and Wehrtmann, 2001; filled plot symbols).

atures rising up to about $18{ }^{\circ} \mathrm{C}$. On the other hand, the benthic juveniles may be more tolerant of those conditions compared to the larval stages, in particular those of northern, more warm-adapted populations. This implies that, like in the Beagle Channel and the adjacent Magellan region, a continued cultivation of juveniles in this area would probably not require energy-consuming and expensive cooling of cultivation tanks.

Our experimental laboratory study not only provides information on optimal temperature conditions for larval and early juvenile rearing of the southern king crab, but our data (cf. Tables 2 and 3) also allow for estimates of seasonal variation of development and growth in the field. In the area of origin of our material, the Beagle Channel, hatching begins in early August when water temperature is about $5{ }^{\circ} \mathrm{C}$ (Fig. 2). First settlement of megalopae, which show largely benthic behaviour and thus terminate the period of demersal planktonic dispersal (see Lovrich et al., 2003, Thatje et al., 2003), should occur from late August or beginning of September; earliest metamorphosis to the first juvenile instar should be expected for early October, roughly coinciding with the end of the hatching period (Lovrich and Vinuesa, 1999). Latest metamorphosis should thus occur about 2 months later, implying that the entire spring season, from October through December, represents the principal period of juvenile settlement and metamorphosis in the Beagle Channel and adjacent areas. In next winter, about 1 year after hatching of a cohort, juvenile king crabs may reach approximately instars VII-VIII.

Assuming a similar temperature dependence of early development in the offspring of northern populations of $L$. santolla, we may estimate also the approximate timing of key events such as settlement and metamorphosis in the region off the island of Chiloe and 
adjacent areas in the Pacific Ocean. Larval hatching appears to occur there slightly earlier than in the Beagle Channel (mostly in August; Paschke, personal communication). At average water temperatures of about $10-12{ }^{\circ} \mathrm{C}$ (see Fig. 2), the demersal-planktonic zoeal phase should be very short, probably not exceeding ca. two weeks (cf. Table 3), and metamorphosis from the megalopa to the first juvenile stage may occur already in September. Within 1 year from hatching, juvenile king crabs may grow there to approximately instar IX.

Similar predictions may be made also for the region where L. santolla reaches its northernmost distributional limit in the Atlantic Ocean, i.e. on the continental slope off Uruguay in ca. $700 \mathrm{~m}$ depth (Vinuesa, 1991). Since the temperatures in this deep-water environment are, throughout the year, similar to those in the Beagle Channel during winter (Guerrero and Piola, 1997), the larval and early juvenile development should be similar as observed in our experiments at $6{ }^{\circ} \mathrm{C}$. This implies that juvenile growth should be slower than in the Beagle Channel, probably reaching only crab instar VI during the first year of postembryonic life.

While it appears that such extrapolations from laboratory observations should allow for fairly reliable predictions of early development and growth in the field, in particular in a species where larval feeding is not a potentially confounding factor, future studies must scrutinize if the temperature dependence of developmental rates in southern and northern populations is really independent of regionally varying climatic conditions. If the relationships between development duration and temperature show a latitudinal shift, this may indicate the occurrence of an evolutionary temperature adaptation (for recent discussion, see Clarke, 2003). As a consequence of physiological compensation mechanisms, the northern populations of L. santolla in Chile would, in this case, show longer periods of larval and early juvenile development than expected from the extrapolation of our present experimental data.

Our observations of larval and early juvenile temperature tolerance suggest that $L$. santolla is a typical cold-eurythermal species, which also explains its wide distributional range extending over about $13^{\circ}$ latitude in the Pacific and almost $20^{\circ}$ in the Atlantic Ocean. Its larvae are able to develop from hatching to at least the last zoeal stage at temperatures as low as $1-3{ }^{\circ} \mathrm{C}$, and all larval stages including the benthic megalopa are fully lecithotrophic, i.e. nonfeeding even when food is available. Very similar developmental traits were recently observed also in another, closely related species from the Beagle Channel, the lithodid crab Paralomis granulosa (Anger et al., 2003; Calcagno et al., 2003, 2004; Kattner et al., 2003). An extreme degree of larval independence from plankton production, in combination with tolerance of low temperatures, has been interpreted as an early life-history adaptation to conditions typically prevailing at high latitudes, i.e. cold stress and seasonally short or unpredictable plankton productivity in winter, when king crab larvae predominantly hatch.

Similar traits have been observed in two lithodid species from the northern hemispere (Anger, 1996; Shirley and Zhou, 1997) and may thus be expected to occur also in further king crab species whose developmental patterns have remained unknown. This suggests that lithodid crabs, including the subantarctic species L. santolla and P. granulosa, belong to the most likely candidates for a possible scenario of a future repopulation of Antarctic waters, from where reptant decapod crustaceans have virtually disappeared during 
Antarctic cooling until the middle Miocene about 15 million years ago (Crame, 1999). If our global climate continues to warm, this might allow for a gradual invasion of polar regions by preadapted subpolar, and perhaps deep-sea dwelling lithodid crabs. Since king crabs show a high species diversity in subpolar and deep sea regions of both hemispheres, and in most of these species the early life history is completely unknown, future experimental studies may reveal further candidates with cold-tolerant and starvationresistant larvae.

\section{Acknowledgements}

We greatly appreciate the help of the crew of PFS "Polarstern" during the transport of live crabs. U. Nettelmann and several students helped in maintaining larval and juvenile cultures. Thanks are also due to Dr. I. Wehrtmann for providing temperature data for Chiloé, Chile. J. Calcagno is grateful to the German Academic Exchange Service (DAAD, Bonn) and the Alfred-Wegener-Institut für Polar- und Meeresforschung (AWI, Bremerhaven) for funding his research visits to Helgoland. G. Lovrich acknowledges additional support from the International Foundation for Science (grant A2507-2). This project was principally funded by the International Bureau of the German Ministry of Scientific Research (BMBF, project no. ARG 99/002), and the Argentine Secretaría de Ciencia, Tecnología e Inovación Productiva (SeCyT). [SS]

\section{References}

Anger, K., 1996. Physiological and biochemical changes during lecithotrophic larval development and early juvenile growth in the northern stone crab, Lithodes maja (Decapoda: Anomura). Mar. Biol. 126, 283 - 296.

Anger, K., Thatje, S., Lovrich, G., Calcagno, J., 2003. Larval and early juvenile development of Paralomis granulosa reared at different temperatures: tolerance of cold and food limitation in a lithodid crab from high latitudes. Mar. Ecol. Prog. Ser. 253, 243-251.

Arntz, W.E., Brey, T., Gallardo, V.A., 1994. Antarctic zoobenthos. Oceanogr. Mar. Biol. Annu. Rev. 32, 241 - 304.

Arntz, W.E., Gutt, J., Klages, M., 1997. Antarctic marine biodiversity: an overview. In: Battaglia, B., Valencia, J., Walton, D.W.H. (Eds.), Antarctic Communities: Species, Structure and Survival. Cambridge Univ. Press, Cambridge, UK, pp. 3-14.

Boschi, E.E., Fischbach, C.E., Iorio, M.I., 1992. Catálago ilustrado de los crustáceos estomatópodos y decápodos marinos de Argentina. Frente Marít., Uruguay 10, 7-94.

Calcagno, J.A., Thatje, S., Anger, K., Lovrich, G.A., Kaffenberger, A., 2003. Changes in biomass and chemical composition during lecithotrophic larval development of the southern stone crab Paralomis granulosa. Mar. Ecol. Prog. Ser. 257, 189-196.

Calcagno, J.A., Anger, K., Lovrich, G.A., Thatje, S., Kaffenberger, A., 2004. Larval development of the subantarctic king crabs Lithodes santolla and Paralomis granulosa reared in the laboratory. Helgol. Mar. Res. 58, $11-14$.

Campodonico, G.I., 1971. Desarrollo larval de la centolla Lithodes antarctica Jacquinot en condiciones de laboratorio (Crustácea Decapoda, Anomura: Lithodidae). An. Inst. Patagon., Ser. Cienc. Nat. (Punta Arenas, Chile) 2, 181-190.

Clarke, A., 2003. Costs and consequences of evolutionary temperature adaptation. Trends Ecol. Evol. 18, 573 - 581.

Crame, J.A., 1999. An evolutionary perspective on marine faunal connections between southernmost South America and Antarctica. Sci. Mar. 63 (Suppl. 1), 1-14. 
Dawson, E.W., 1989. King crabs of the world (Crustacea: Lithodidae) and their fisheries: a comprehensive bibliography. Misc. Publ.-N.Z. Oceanogr. Inst. Div. Water Sci., vol. 101. DSIR, Wellington, pp. 1-338.

Gorny, M., 1999. On the biogeography and ecology of the Southern Ocean decapod fauna. Sci. Mar. 63 (Suppl. 1), $367-382$.

Guerrero, R.A., Piola, A.R., 1997. Masas de agua en la plataforma continental. In: Boschi, E.E. (Ed.), El Mar Argentino y sus recursos pesqueros. Antecedentes históricos de las exploraciones en el mar y las características ambientales, vol. 1. Instituto Nacional de Investigación y Desarrollo Pesquero (INIDEP), Mar del Plata, Argentina, pp. 107-118.

Kattner, G., Graeve, M., Calcagno, J.A., Lovrich, G.A., Thatje, S., Anger, K., 2003. Lipid, fatty acid and protein utilization during lecithotrophic larval development of Lithodes santolla (Molina) and Paralomis granulosa (Jacquinot). J. Exp. Mar. Biol. Ecol. 292, 61-74.

Klages, M., Gutt, J., Starmans, A., Bruns, T., 1995. Stone crabs close to the Antarctic continent: Lithodes murrayi Henderson, 1888 (Crustacea; Decapoda; Anomura) off Peter I Islands (68 $51^{\prime} \mathrm{S}, 90^{\circ} 51^{\prime} \mathrm{W}$ ). Polar Biol. 15, $73-75$.

Konishi, K., 1998. Production of juveniles of shrimps and crabs in Japan. Farming Jpn. 32, 28 - 37.

Konishi, K., Shikatani, N., 1999. Identification manual for larvae of commercially important crabs in Japan: II. Anomuran crabs. Bull. Natl. Res. Inst. Aquac. 28, 5-13.

Lardies, M.A., Wehrtmann, I.S., 2001. Latitudinal variation in the reproductive biology of Betaeus truncatus (Decapoda: Alpheidae) along the Chilean coast. Ophelia 55, 55-67.

Lovrich, G.A., 1997. La pesquería mixta de las centollas Lithodes santolla y Paralomis granulosa (Anomura: Lithodidae) en Tierra del Fuego, Argentina. Invest. Mar. (Valparaíso) 25, 41-57.

Lovrich, G.A., Vinuesa, J.H., 1999. Reproductive potential of the lithodids Lithodes santolla and Paralomis granulosa (Anomura, Decapoda) in the Beagle Channel, Argentina. Sci. Mar. 63 (Suppl. 1), 355-360.

Lovrich, G.A., Thatje, S., Calcagno, J.A., Anger, K., Kaffenberger, A., 2003. Changes in biomass and chemical composition during lecithotrophic larval development of the southern king crab, Lithodes santolla (Molina). J. Exp. Mar. Biol. Ecol. 288, 65-79.

McLaughlin, P.A., Anger, K., Kaffenberger, A., Lovrich, G.A., 2001. Megalopal and early juvenile development in Lithodes santolla (Molina, 1782) (Decapoda: Anomura; Paguroidea: Lithodidae), with notes on zoeal variations. Invertebr. Reprod. Dev. 40, 53-67.

Retamal, M.A., 1981. Catálogo ilustrado de los Crustáceos Decápodos de Chile. Gayana, Zool., vol. 44 Universidad De Concepción, Chile, pp. 1-110.

Shirley, T.C., Zhou, S., 1997. Lecithotrophic development of the golden king crab Lithodes aequispinus (Anomura: Lithodidae). J. Crustac. Biol. 17, 207-216.

Sokal, R.R., Rohlf, F.J., 1995. Biometry. The Principles and Practice of Statistics in Biological Research. Freeman, New York, NY. 887 pp.

Stevens, B.G., 2003. Settlement, substratum preference, and survival of red king crab Paralithodes camtschaticus (Tilesius, 1815) glaucothoe on natural substrata in the laboratory. J. Exp. Mar. Biol. Ecol. 283, 63-78.

Sundet, J.H., Hjelset, A.M., 2002. The Norwegian red king crab (Paralithodes camtschaticus) fishery: management and bycatch issues. In: Paul, A.J., Dawe, E.G., Elner, R., Jamieson, G.S., Kruse, G.H., Otto, R.S., Sainte-Marie, B., Shirley, T.C., Woodby, D. (Eds.), Crabs in Cold Water Regions: Biology, Management, and Economics, University of Alaska, Fairbanks, AK, USA, pp. 681-692. Sea Grant College Program AK-SG-02-01

Thatje, S., Calcagno, J.A., Lovrich, G.A., Sartoris, F.J., Anger, K., 2003. Extended hatching periods in the subantarctic lithodid crabs Lithodes santolla and Paralomis granulosa (Crustacea: Decapoda: Lithodidae). Helgol. Mar. Res. 57, 110-113.

Vinuesa, J.H., 1991. Biologia y pesqueria de la centolla (Lithodes santolla). Rio Grande (Atlantica) 13, 233 - 244.

Zaklan, S.D., 2002. Review of the family Lithodidae (Crustacea: Anomura: Paguroidea): distribution, biology, and fisheries. In: Paul, A.J., Dawe, E.G., Elner, R., Jamieson, G.S., Kruse, G.H., Otto, R.S., Sainte-Marie, B., Shirley, T.C., Woodby, D. (Eds.), Crabs in Cold Water Regions: Biology, Management, and Economics, University of Alaska, Fairbanks, AK, USA, pp. 751-845. Sea Grant College Program AK-SG-02-01. 